\title{
Phytoprotection
}

\section{Susceptibility of the Japanese beetle, Popillia japonica (Newman) (Coleoptera: Scarabaeidae), to entomopathogenic Hypocreales fungi \\ Vulnérabilité du scarabée japonais, Popillia japonica (Newman) (Coleoptera : Scarabaeidae), aux champignons pathogènes de l'ordre Hypocreales}

\author{
François Giroux, Robert Lavallée, Éric Bauce et Claude Guertin
}

Volume 95, numéro 1, 2015

URI : https://id.erudit.org/iderudit/1028399ar

DOI : https://doi.org/10.7202/1028399ar

Aller au sommaire du numéro

Éditeur(s)

Société de protection des plantes du Québec (SPPQ)

ISSN

1710-1603 (numérique)

Découvrir la revue

Citer cet article

Giroux, F., Lavallée, R., Bauce, É. \& Guertin, C. (2015). Susceptibility of the Japanese beetle, Popillia japonica (Newman) (Coleoptera: Scarabaeidae), to entomopathogenic Hypocreales fungi. Phytoprotection, 95(1), 1-6.

https://doi.org/10.7202/1028399ar

\section{Résumé de l'article}

La vulnérabilité des adultes et des larves du scarabée japonais aux isolats des champignons Beauveria bassiana, B. brongniartii, Metarhizium anisopliae, Lecanicillium longisporum et L. muscarium (Ascomycota : Hypocreales) a été évaluée lors de tests biologiques en laboratoire. La présence de variations intra- et interspécifiques concernant le pouvoir pathogène des isolats a été étudiée. Les résultats montrent que la plupart des isolats fongiques provoquent de la mortalité chez les adultes et les larves. Les isolats $M$. anisopliae INRS 705 et $B$. bassiana INRS 236 ont mené à des taux de mortalité de $70,3 \%$ et $65,2 \%$ chez les adultes de $P$. japonica, respectivement, et les deux isolats ont provoqué la mort d'environ $37 \%$ des larves. Des 17 isolats testés, 13 ont causé de la mortalité larvaire. Cependant, aucune différence importante n’a été notée entre la vulnérabilité des larves aux isolats de différentes espèces et à ceux de la même espèce. Les espèces Lecanicillium n'ont clairement pas de pouvoir pathogène chez les adultes et semblent n'avoir que peu d'effet chez les larves. En se fondant sur les résultats obtenus avec les isolats choisis, des différences intra- et interspécifiques concernant le pouvoir pathogène des isolats semblent être présentes. Dans son ensemble, l'étude a permis d'accroître les connaissances sur la vulnérabilité de $P$. japonica aux champignons pathogènes de l'ordre Hypocreales. Les conséquences de cette étude pour le développement d'un biopesticide sont présentées. 


\title{
Susceptibility of the Japanese beetle, Popillia japonica (Newman) (Coleoptera: Scarabaeidae), to entomopathogenic Hypocreales fungi
}

\author{
François Giroux ${ }^{1}$, Robert Lavallée ${ }^{2}$, Éric Bauce $^{3}$ and Claude Guertin ${ }^{1 凶}$ \\ Received on 2014-05-13; accepted on 2014-09-23
}

\section{PHYTOPROTECTION $95:$ 1-6}

The susceptibility of adults and larvae of the Japanese beetle to isolates of the fungi Beauveria bassiana, B. brongniartii, Metarhizium anisopliae, Lecanicillium longisporum and L. muscarium (Ascomycota: Hypocreales) was evaluated in laboratory bioassays. The presence of intra- and interspecific variations regarding the pathogenicity of the isolates was investigated. Results show that most of the fungal isolates caused mortality in adults and larvae. Isolates M. anisopliae INRS 705 and $B$. bassiana INRS 236 induced $70.3 \%$ and $65.2 \%$ of mortality in P. japonica adults, respectively, and both caused the death of about $37 \%$ of larvae. Of the 17 tested isolates, 13 caused larval mortality. However, no significant difference was found between the susceptibility of larvae to isolates from different species and those from a same species. Lecanicillium species are undoubtedly not pathogenic to adults and seem to have few effects on larvae. Based on the results obtained with the selected isolates, intra- and interspecific differences relative to the pathogenicity of the isolates appeared to be present. Overall, this study expanded the knowledge about $P$. japonica susceptibility towards entomopathogenic Hypocreales fungi. The implications of this study regarding the development of a biological control agent are discussed.

Keywords: Beauveria bassiana, Japanese beetle, Lecanicillium longisporum, Lecanicillium muscarium, Metarhizium anisopliae, microbial control, Popillia japonica.

[Vulnérabilité du scarabée japonais, Popillia japonica (Newman) (Coleoptera : Scarabaeidae), aux champignons pathogènes de l'ordre Hypocreales]

La vulnérabilité des adultes et des larves du scarabée japonais aux isolats des champignons Beauveria bassiana, B. brongniartii, Metarhizium anisopliae, Lecanicillium longisporum et L. muscarium (Ascomycota : Hypocreales) a été évaluée lors de tests biologiques en laboratoire. La présence de variations intra- et interspécifiques concernant le pouvoir pathogène des isolats a été étudiée. Les résultats montrent que la plupart des isolats fongiques provoquent de la mortalité chez les adultes et les larves. Les isolats $M$. anisopliae INRS 705 et $B$. bassiana INRS 236 ont mené à des taux de mortalité de $70,3 \%$ et $65,2 \%$ chez les adultes de $P$. japonica, respectivement, et les deux isolats ont provoqué la mort d'environ $37 \%$ des larves. Des 17 isolats testés, 13 ont causé de la mortalité larvaire. Cependant, aucune différence importante n'a été notée entre la vulnérabilité des larves aux isolats de différentes espèces et à ceux de la même espèce. Les espèces Lecanicillium n'ont clairement pas de pouvoir pathogène chez les adultes et semblent n'avoir que peu d'effet chez les larves. En se fondant sur les résultats obtenus avec les isolats choisis, des différences intra- et interspécifiques concernant le pouvoir pathogène des isolats semblent être présentes. Dans son ensemble, l'étude a permis d'accroître les connaissances sur la vulnérabilité de $P$. japonica aux champignons pathogènes de l'ordre Hypocreales. Les conséquences de cette étude pour le développement d'un biopesticide sont présentées.

Mots-clés : Beauveria bassiana, Lecanicillium longisporum, Lecanicillium muscarium, lutte microbienne, Metarhizium anisopliae, Popillia japonica, scarabée japonais.

1. INRS-Institut Armand-Frappier, Laval, OC, Canada H7V 1B7; corresponding author e-mail: claude.guertin@iaf.inrs.ca

2. Natural Resources Canada, Canadian Forest Service, Québec, QC, Canada G1V 4C7

3. Université Laval, Québec, QC, Canada G1V 0A6 


\section{INTRODUCTION}

The Japanese beetle, Popillia japonica (Newman), was first reported in Canada in 1938 (CFIA 2009). Since then, this insect has never stopped spreading northward. Japanese beetle is becoming an increasing problem in tree nurseries in Canada, and it particularly affects the provinces of Ontario and Quebec. Adults feed on more than 300 species of plants and are thus considered among the most aggressive polyphagous plant-feeding insects (Potter and Held 2002). Turf roots are the preferred host of the larvae (grubs), but other host plants may also be attacked.

Tree nurseries significantly contribute to the success of reforestation programs. In the province of Quebec, 130 million seedlings are produced annually by nurseries (MRN 2014). The use of chemical insecticides is necessary to reduce the damage caused to nursery plants and to decrease the risk of insect dispersal. However, as the populations of Japanese beetle will most likely increase in Canada, more environmentally acceptable approaches to $P$. japonica population control are required.

Several microbiological agents have been studied for their potential to regulate larval populations of the Japanese beetle, including the bacteria Bacillus thuringiensis serovar japonensis strain Buibui (Ohba et al. 1992; Alm et al. 1997; Koppenhofer et al. 2000; Bixby et al. 2007), B. thuringiensis subsp. galleriae SDS-502 (Yamaguchi et al. 2013) and Paenibacillus popilliae (formely Bacillus popilliae) (Bulla et al. 1975; Klein 1992; Redmond and Potter 1995; Matsuki et al. 1997; Rippere et al. 1998), the nematodes Steinernema glaseri Steiner and Heterorhabditis bacteriophora Poinar, and the fungi Metarhizium anisopliae (Lacey et al. 1994; Villani et al. 1994; Lacey et al. 1995b; Abalos et al. 2001; Cappaert and Smitley 2002; Petty et al. 2012) and Beauveria bassiana (Hanula and Andreadis 1988; Hanula et al. 1991; Klein 1992; Lacey et al. 1995a, b; Bixby et al. 2007).

There are few conclusive studies on the effectiveness of entomopathogenic fungi against $P$. japonica. This study was conducted to determine and compare the impact of different species of Hypocreales fungi with the goal of identifying the one possessing maximum virulence against larvae and adults of $P$. japonica. Several fungal isolates were screened to verify their entomopathogenic potential against both developmental stages of the Japanese beetle.

\section{MATERIAL AND METHODS}

\section{Insects}

Adults and larvae of the Japanese beetle were collected from a public tree nursery located near Berthierville, approximately $50 \mathrm{~km}$ northeast of Montreal, QC, Canada $\left(45.99^{\circ} \mathrm{N},-73.19^{\circ} \mathrm{W}\right)$, in 2010.

At the end of April, about 2 mo before adult emergence, larvae were collected for bioassays. Larvae were harvested in grass near an ash tree (Fraxinus spp.) plantation, an area seriously affected by Japanese beetles. The extraction was facilitated using a tractor that cut ground slices (approximately $15 \mathrm{~cm}$ thick). Ground slices were transferred to an elevated shaking conveyor that let the larvae fall to the ground. Japanese beetle larvae were differentiated from other insect larvae present in the soil by their typical creamy white colour and C-shaped body. Larvae collected in the field were brought to the laboratory for subsequent experiments. In order to ensure the viability of the larvae until the bioassay, they were kept in plastic boxes filled with soil and covered by a turf layer originating from the sampling site.

Adults were collected using Japanese beetle traps (Trécé Inc., Adair, OK, USA) previously placed in the field at the Berthierville tree nursery. The traps were baited with a mixture of two compounds: japonilure $\left(\mathrm{C}_{14} \mathrm{H}_{24} \mathrm{O}_{2}\right.$, CSA\# 64726-91-6), a sexual pheromone (Tumlinson et al. 1977), and an attractant food-type lure [eugenol $\left(\mathrm{C}_{10} \mathrm{H}_{12} \mathrm{O}_{2}, \mathrm{CSA \#} \mathrm{97-53-0),2-phenylethyl}\right.$ propionate $\left(\mathrm{C}_{11} \mathrm{H}_{14} \mathrm{O}_{2}\right.$, CSA\# 122-70-3); and geraniol $\left(\mathrm{C}_{10} \mathrm{H}_{18} \mathrm{O}\right.$, CSA\# 106-24-1) in a ratio of 7:3:3] (Ladd et al. 1984). The adults were caught the day before the bioassay.

\section{Fungal isolates}

The entomopathogenic isolates used in the subsequent bioassays originated from the microfungal collection of the INRS-Institut Armand-Frappier. The selected fungi were associated with three different genera (Beauveria, Metarhizium and Lecanicillium) and related to the order Hypocreales. A total of 19 isolates belonging to five species (Beauveria bassiana (Bals.-Criv.) Vuill., Beauveria brongniartii (Sacc.) Petch, Metarhizium anisopliae Metschn.) Sorokin, Lecanicillium longisporum R. Zare \& W. Gams and Lecanicillium muscarium R. Zare \& W. Gams) were used for the bioassays (Table 1).

\section{Inoculum preparation and solid-stage culture conditions}

Fungal isolates were first incubated at $25 \pm 1{ }^{\circ} \mathrm{C}$ for $7 \mathrm{~d}$ in Petri dishes containing Sabouraud Dextrose Agar (SDA). The conidia and the mycelium were harvested and dispersed in $10 \mathrm{~mL}$ of sterile distilled water by scraping the surface with a sterile scalpel blade under strictly aseptic conditions. The suspensions thus obtained were subsequently submitted to a solidstate fermentation production using barley (Hordeum vulgare L.) as substrate and spawn bags. For each isolate tested, three bags were prepared. In each of them, $200 \mathrm{~g}$ of barley were mixed thoroughly with $100 \mathrm{~mL}$ of water, then autoclaved at $121^{\circ} \mathrm{C}$ for $20 \mathrm{~min}$. Once the solid medium was cooled, $10 \mathrm{~mL}$ of a fungal suspension was added to each bag, and the conidia and mycelium were methodically mixed for a better dispersion within the substrate. After the incubation period, $400 \mathrm{~mL}$ of deionized water was added to each bag and mixed thoroughly to liberate the conidia. The suspension was then filtered through three layers of sterile cheesecloth, and the concentration of conidia was assessed using a standard (improved Neubauer) hemocytometer. The viability of conidia of each suspension was also evaluated by measuring the percentage of germination as described by Inglis et al. (1993). At least 200 conidia were examined for each germination test. For all isolates, the germination rate was between $97 \%$ and $100 \%$ after $24 \mathrm{~h}$. All conidia suspensions were kept at $4{ }^{\circ} \mathrm{C}$ until their use in bioassays. 
Table 1. Species of Hypocreales fungi used in this study.

\begin{tabular}{|c|c|c|c|c|}
\hline \multirow[t]{2}{*}{ Species } & \multirow[t]{2}{*}{ Isolates } & \multicolumn{2}{|c|}{ Bioassays performed on } & \multirow[t]{2}{*}{ Host or other reference } \\
\hline & & Larvae & Adults & \\
\hline \multirow[t]{7}{*}{ Beauveria bassiana } & INRS 236 & Yes & Yes & Daom $^{1} 210569$ \\
\hline & INRS 261 & Yes & Yes & $\mathrm{LRS}^{2} 100$ \\
\hline & INRS 209 & No & Yes & Arsef $^{3} 1956$ \\
\hline & INRS 227 & No & Yes & Daom 71453 \\
\hline & INRS 200 & Yes & Yes & Arsef 252 \\
\hline & INRS 242 & Yes & Yes & Tomicus piniperda L. \\
\hline & INRS 243 & Yes & Yes & Leptinotarsa decemlineata (Say) \\
\hline \multirow[t]{4}{*}{ Beauveria brongniartii } & INRS 600 & Yes & Yes & Arsef 659 \\
\hline & INRS 603 & Yes & Yes & LRS 24 \\
\hline & INRS 604 & Yes & Yes & LRS 25 \\
\hline & INRS 602 & Yes & Yes & LRS 23 \\
\hline \multirow[t]{6}{*}{ Metarhizium anisopliae } & INRS 706 & Yes & Yes & $\mathrm{UAMH}^{4} 1674$ \\
\hline & INRS 701 & Yes & Yes & UAMH 4450 \\
\hline & INRS 705 & Yes & Yes & UAMH 9198 \\
\hline & INRS 707 & Yes & Yes & UAMH 2801 \\
\hline & INRS 704 & Yes & Yes & UAMH 9197 \\
\hline & INRS 700 & Yes & Yes & UAMH 421 \\
\hline Lecanicillium longisporum & INRS 1105 & Yes & Yes & Vertalec, Koppert Biological Systems \\
\hline Lecanicillium muscarium & INRS 1106 & Yes & Yes & Mycotal, Koppert Biological Systems \\
\hline
\end{tabular}

1 National Mycology Herbarium of the Eastern Cereal and Oilseed Research Centre, Agriculture and Agri-Food Canada.

2 USDA-ARS Collection of Entomopathogenic Fungi.

3 Lethbridge Research Centre, Agriculture and Agri-Food Canada.

4 University of Alberta Microfungus Collection and Herbarium.

\section{Bioassays}

Bioassays of all fungal isolates were carried out against larvae and adults of the Japanese beetle at an inoculum concentration of $8 \times 10^{10}$ conidia/mL. For each fungal isolate, bioassays were replicated three times. For adults, 20 individuals per replicate were used to evaluate the pathogenicity of the different Hypocreales fungi (Table 1). For larvae, each bioassay was performed using 10 individuals per replicate. Adults and larvae were individually inoculated by immersion in a vial containing $10 \mathrm{~mL}$ of fungal suspension. The vial was capped and inverted five times over a $5 \mathrm{~s}$ period to increase the probability of the insect being completely drenched with fungal suspension. The suspension and insect were filtered through a plastic strainer $(7 \mathrm{~cm}$ diam). For controls, both stages of the insect were treated with distilled sterile water. Treated and untreated adults were individually transferred into a $29.5 \mathrm{~mL}$ cup (P100-0100; Solocup, IL, USA) containing sterile filter papers on the bottom. The larvae, which are more sensitive to desiccation, were placed into cups containing sterilized soil to provide support and avoid death by desiccation. In both cases, the cups were incubated at $25 \pm 1{ }^{\circ} \mathrm{C}$. The mortality of both adults and larvae were assessed after $14 \mathrm{~d}$.

\section{Statistical analysis}

The bioassay data does not follow a normal distribution. Therefore, a non-parametric Kruskal-Wallis oneway analysis of variance was performed to see if there was any difference in the mortality associated with isolates. When the difference was statistically significant, a Mann-Whitney test was performed to analyse the response of specific pairs of isolates.

\section{RESULTS AND DISCUSSION}

The bioassays conducted on adults of the Japanese beetle show considerable variability among the 19 isolates of Hypocreales fungi (Fig. 1). Significant intra- and interspecific variability was found between the tested isolates (Wilcoxon-Mann-Whitney test, $p=$ $0.0023)$. Both Lecanicillium isolates do not have any impact on the mortality of adults. On the other hand, M. anisopliae INRS 705 and B. bassiana INRS 236 isolates induced high levels of mortality in adults $(70.3 \%$ and $65.2 \%$, respectively). These results are in accordance with those of previous studies, which showed mortality rates near $60 \%$ and $79 \%$ after exposure of $P$. japonica adults to $M$. anisopliae and $B$. bassiana isolates, respectively (Lacey et al. 1994, 1995b; Klein and Lacey 1999). However, for each fungal species, variation in susceptibility to isolates was observed in adults. Mortality rate varied from 0 to $70.3 \%$ for $M$. anisopliae, from 0 to $65.2 \%$ for $B$. bassiana, and from 10.5 to $38.8 \%$ for $B$. brongniartii.

Several factors, such as the dose used (Vandenberg et al. 1998), food sources and the presence of fungal inhibitors (Hare and Andreadis 1983; Ramoska and 


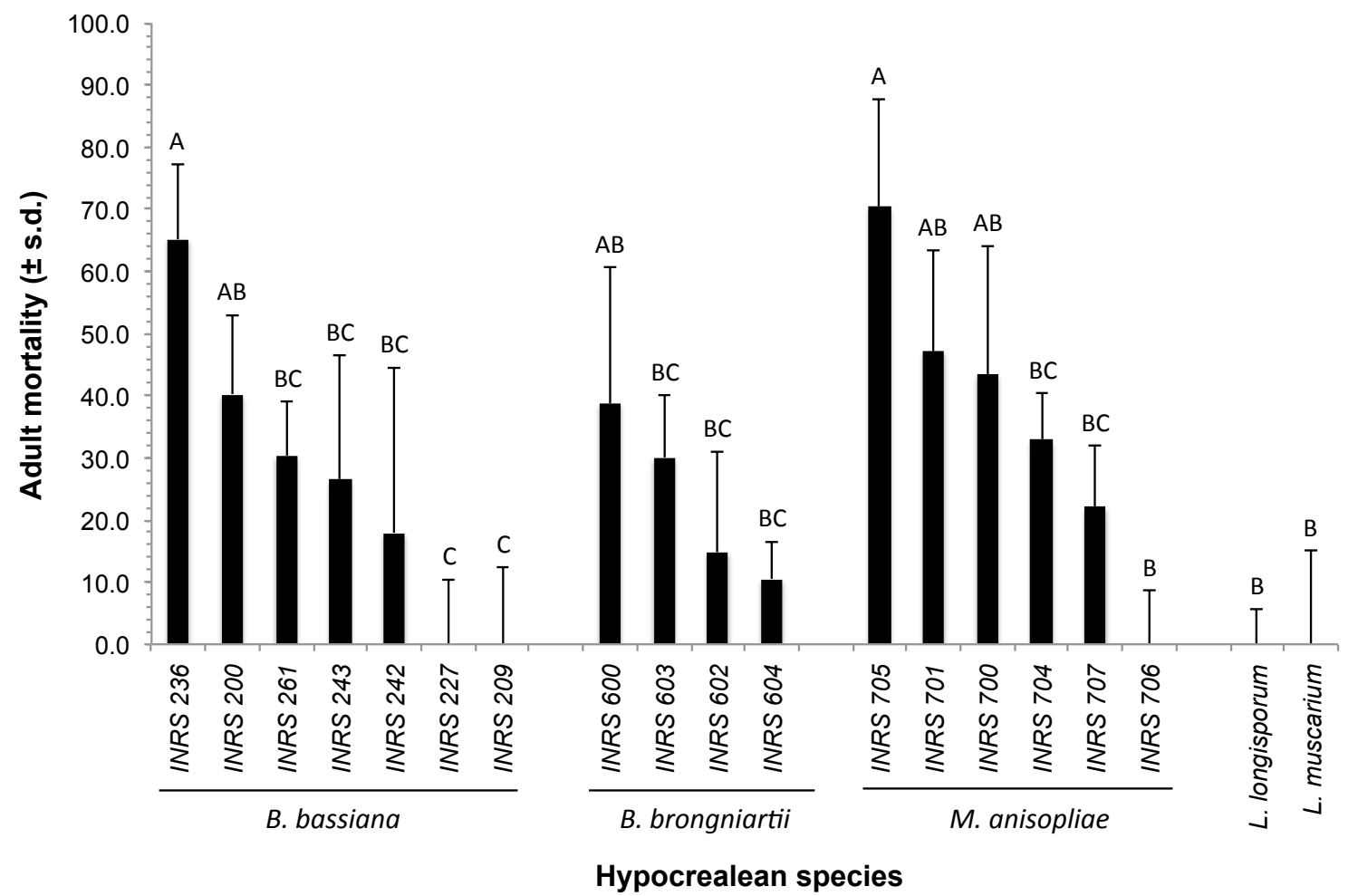

Fig. 1. Percentage of mortality of Japanese beetle adults exposed to 19 isolates of Hypocreales fungi (Beauveria bassiana, Beauveria brongniartii, Metarhizium anisopliae, Lecanicillium longisporum and Lecanicillium muscarium). Means with the same letter are not significantly different.

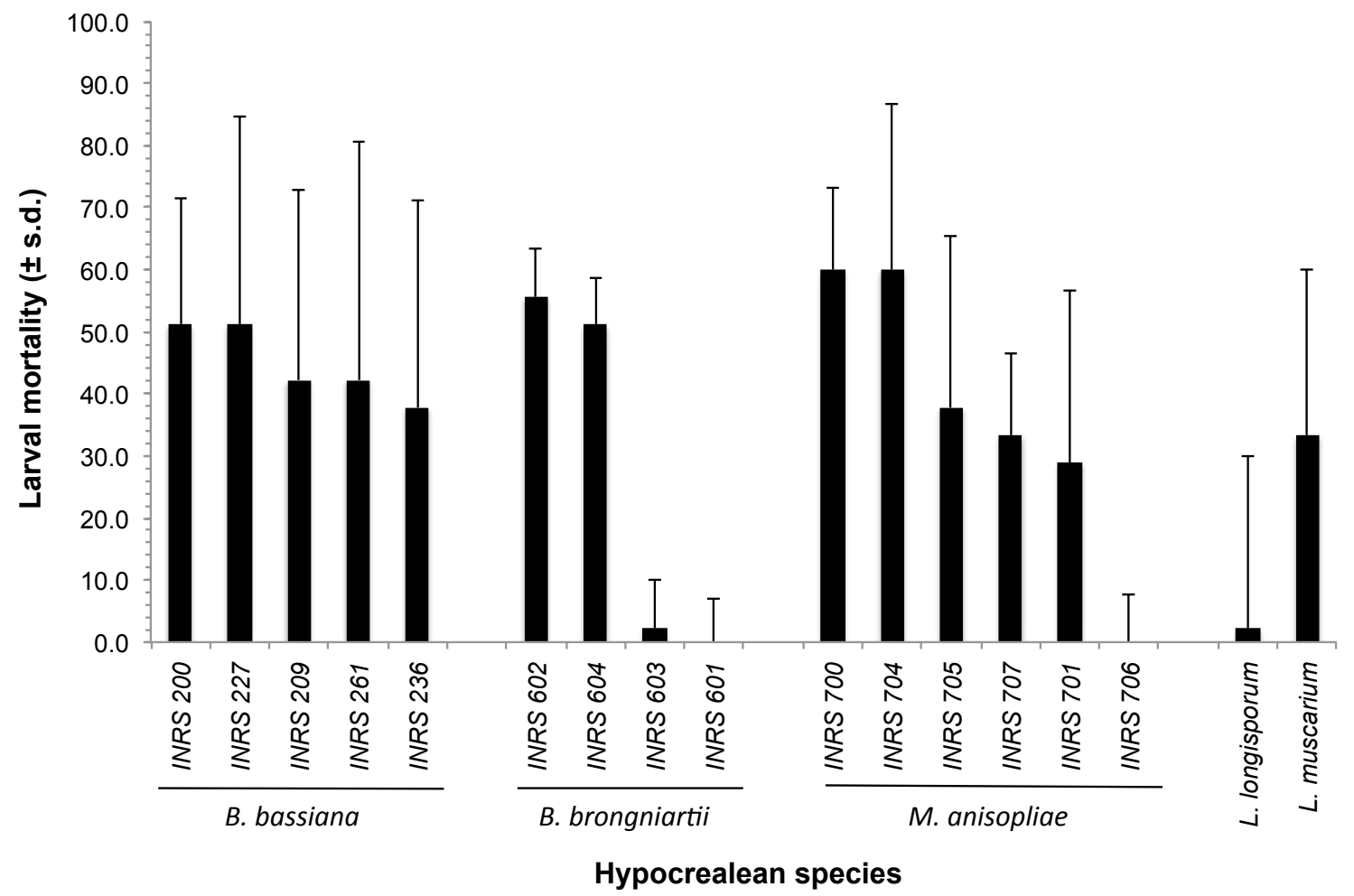

Fig. 2. Percentage of mortality of Japanese beetle larvae exposed to 17 isolates of Hypocreales fungi (Beauveria bassiana, Beauveria brongniartii, Metarhizium anisopliae, Lecanicillium longisporum and Lecanicillium muscarium). No significant difference was found between isolates. 
Todd 1985), temperature (Vandenberg et al. 1998), and insect developmental stage (Vandenberg et al. 1998), may affect the pathogenicity of an entomopathogenic fungal isolate. However, these factors cannot explain the variation in mortality observed within the species tested. An individual isolate can exhibit a substantially restricted host range (Inglis et al. 2001). Moreover, isolates recovered from a closely related species are generally more virulent than isolates from non-related species (Sabbahi et al. 2008). Out of all the isolates tested, our results demonstrate the effectiveness of $M$. anisopliae INRS 705, which was isolated from soil sample, and $B$. bassiana INRS 236, which comes from a green metallic coleopteran insect. Both isolates seem to be good candidates for the biological control of adults of the Japanese beetle.

As with adults, an important variability in the susceptibility of Japanese beetle larvae exposed to 17 Hypocreales isolates was observed (Fig. 2). The highest mortality rates, which were superior to $55 \%$, were recorded for $B$. bassiana INRS 200 and INRS 227, and for M. anisopliae INRS 602 and INRS 604. The susceptibility of larvae to $B$. brongniartii strongly varies between isolates, ranging from 0 (INRS 601) to $55.6 \%$ (INRS 602). Finally, the mortality rates recorded for isolates belonging to the Lecanicillium genus were 2.2 and $33.3 \%$ for $L$. longisporum and L. muscarium, respectively. However, no significant differences were detected when the Wilcoxon-Mann-Whitney test was applied to the results of all isolates $(p \geq 0.05)$.

Only a few studies have demonstrated the potential of Hypocreales fungi for larval control (Krueger et al. 1991; Villani and Krueger 1994). The variability in mortality observed for each isolate and the lack of significant results allowing the identification of the most effective isolate may be attributed to the low number of larvae used for each replicate $(n=10)$. Experiments using less isolates and a higher number of larvae could be repeated with the most effective $B$. bassiana, B. brongniartii and $M$. anisopliae isolates. Although no statistically significant difference was observed, a positive trend in larval mortality rates can be distinguished in the bioassay using these three Hypocreales species. More specifically, the results obtained with $B$. bassiana INRS 200 and INRS 227, B. brongniartii INRS 602 and INRS 604, and $M$. anisopliae INRS 700 and INRS 704 suggest that biological approaches using these Hypocreales fungi can be effectively implemented to control populations of Japanese beetle larvae.

Larvae of $P$. japonica should be considered an important target in biological control programs in order to minimize the damage they induce to crops. The low mobility of larvae may facilitate the control of these populations (Potter and Held 2002). This study shows the potential of some Hypocreales isolates to control population of Japanese beetles. However, further studies will be needed to confirm the pathogenicity of the selected isolates and to implement efficient integrated management programs against larvae and adults of the Japanese beetle.

\section{ACKNOWLEDGEMENTS}

We thank Marie-Josée Gilbert and Anne Déziel from the Berthierville public tree nursery (Ministère des Forêts, Faune et Parcs du Québec) for technical support during field work. This research was funded by the iFor Research Consortium, the Natural Sciences and Engineering Research Council of Canada, the ministère des Forêts, Faune et Parcs du Québec, the Conseil de l'industrie forestière du Québec, the Canadian Forest Service, and the Société de protection des forêts contre les insectes et maladies du Québec.

\section{REFERENCES}

Abalos, A., A. Pinazo, M.R. Infante, M. Casals, F. Garcia, and A. Manresa. 2001. Physicochemical and antimicrobial properties of new rhamnolipids produced by Pseudomonas aeruginosa AT10 from soybean oil refinery wastes. Langmuir 17 : 1367-1371.

Alm, S.R., M.G. Villani, T. Yeh, and R. Shutter. 1997. Bacillus thuringiensis serovar japonensis strain Buibui for the control of Japanese beetle larvae (Coleoptera: Scarabaeidae). Appl. Entomol. Zool. 32 : 477-484.

Bixby, A., S.R. Alm, K. Power, P. Grewal, and S.R. Swier. 2007. Susceptibility of four species of turfgrass-infesting scarabs (Coleoptera: Scarabaeidae) to Bacillus thuringiensis serovar japonensis strain Buibui. J. Econ. Entomol. 100 : 1604-1610.

Bulla, L.A., R.A. Rhodes, and G. St. Julian. 1975. Bacteria as insect pathogens. Annu. Rev. Microbiol. 29 : 163-190.

Cappaert, D.L., and D.R. Smitley. 2002. Parasitoids and pathogens of Japanese beetle (Coleoptera: Scarabaeidae) in southern Michigan. Environ. Entomol. 31 : 573-580.

CFIA. 2009. Questions and answers: Japanese beetle (Popillia japonica). Canadian Food Inspection Agency. Available online at

http://www.inspection.gc.ca/english/plaveg/pestrava/ popjap/queste.shtml (Accessed on March 31, 2014).

Hanula, J.L., and T.G. Andreadis. 1988. Parasitic microorganisms of Japanese beetles (Coleoptera: Scarabaeidae) and associated scarab larvae in Connecticut soils. Environ. Entomol. 17: 709-714.

Hanula, J.L., T.G. Andreadis, and M. Blackwell. 1991. Entoderma colletosporium gen. and sp. nov., a unique cuticular fungus infecting japanese beetle, Popillia japonica (Coleoptera: Scarabaeidae). J. Invertebr. Pathol. 58 : 327-334.

Hare, J.D., and T.G. Andreadis. 1983. Variation in the susceptibility of Leptinotarsa decemlineata (Coleoptera: Chrysomelidae) when reared on different host plants to the fungal pathogen, Beauveria bassiana in the field and laboratory. Environ. Entomol. 12 : 1892-1897.

Inglis, G.D., M.S. Goettel, and D.L. Johnson. 1993. Persistence of the entomopathogenic fungus, Beauveria bassiana, on phylloplanes of crested wheatgrass and alfalfa. Biol. Control $3: 258-270$.

Inglis, G.D., M.S. Goettel, T.M. Butt, and H. Strasser. 2001. Use of Hyphomycetous fungi for managing insect pests. Pages 23-96 in T.M. Butt, C. Jackson, and N. Magan (eds.), Fungi as Biocontrol Agents: Progress, Problems and Potential. CABI Publishing, Wallingford, UK.

Klein, M.G. 1992. Use of Bacillus popilliae in Japanese beetle control. Pages 179-189 in T.R. Glare and J.T.A. Jackson (eds.), Use of Pathogens in Scarab Pest Management. Intercept Ltd., Hampshire, UK.

Klein, M.G., and L.A. Lacey. 1999. An attractant trap for autodissemination of entomopathogenic fungi into populations of the Japanese beetle Popillia japonica (Coleoptera: Scarabaeidae). Biocontrol Sci. Technol. 9 : 151-158. 
Koppenhofer, A.M., M. Wilson, I. Brown, H.K. Kaya, and R. Gaugler. 2000. Biological control agents for white grubs (Coleoptera: Scarabaeidae) in anticipation of the establishment of the Japanese beetle in California. J. Econ. Entomol. 93 : 71-80.

Krueger, S.R., M.G. Villani, J.P. Nyrop, and D.W. Roberts. 1991. Effect of soil environment on the efficacy of fungal pathogens against scarab grubs in laboratory bioassays. Biol. Control $1: 203-209$.

Lacey, L.A., A. Martins, and C. Ribeiro. 1994. The pathogenicity of Metarhizium anisopliae and Beauveria bassiana for adults of the Japanese beetle, Popillia japonica (Coleoptera: Scarabaeidae). Eur. J. Entomol. 91 : 313-319.

Lacey, L.A., H.K. Kaya, and R. Bettencourt. 1995a. Dispersal of Steinernema glaseri (Nematoda: Steinernematidae) in adult Japanese beetles, Popillia japonica (Coleoptera: Scarabaeidae). Biocontrol Sci. Technol. 5 : 121-130.

Lacey, L.A., J.J. Amaral, J. Coupland, M.G. Klein, and A.M. Simoes. 1995b. Flight activity of Popillia japonica (Coleoptera: Scarabaeidae) after treatment with Metarhizium anisopliae. Biol. Control 5 : 167-172.

Ladd, T.L., J.D. Warthen, and M.G. Klein. 1984. Japanese beetle (Coleoptera: Scarabaeidae): The effects of azadirachtin on the growth and development of the immature forms. J. Econ. Entomol. 77 : 903-905.

Matsuki, N., S. Asano, H. Bando, and T. lizuka. 1997. New Japanese isolates of Bacillus popilliae isolated from milky diseased larvae of Popillia japonica, Anomala rufocuprea and Anomala daimiana (Coleoptera: Scarabaeidae). Appl. Entomol. Zool. 32 : 583-588.

MFFP. 2014. Sources de semences forestières. Ministère des Forêts, Faune et Parcs du Québec, Québec, QC.

Ohba, M., H. Iwahana, S. Asano, N. Suzuki, R. Sato, and H. Hori. 1992. A unique isolate of Bacillus thuringiensis serovar japonensis with a high larvicidal activity specific for scarabaeid beetles. Lett. Appl. Microbiol. 14 : 54-57.

Petty, B.M., D.T. Johnson, and D.C. Steinkraus. 2012. Survey of pathogens and parasitoids of Popillia japonica (Coleoptera: Scarabaeidae) in northwest Arkansas. J. Invertebr. Pathol. 111 : 56-59.
Potter, D.A., and D.W. Held. 2002. Biology and management of the Japanese beetle. Annu. Rev. Entomol. 47 : 175-205.

Ramoska, W.A., and T. Todd. 1985. Variation in efficacy and viability of Beauveria bassiana in the chinch bug (Hemiptera: Lygaeidae) as a result of feeding activity on selected host plants. Environ. Entomol. 14 : 146-148.

Redmond, C.T., and D.A. Potter. 1995. Lack of efficacy of in vivo- and putatively in vitro-produced Bacillus popilliae against field populations of Japanese beetle (Coleoptera: Scarabaeidae) grubs in Kentucky. J. Econ. Entomol. 88 : 846-854.

Rippere, K.E., M.T. Tran, A.A. Yousten, K.H. Hilu, and M.G. Klein. 1998. Bacillus popilliae and Bacillus lentimorbus, bacteria causing milky disease in Japanese beetles and related scarab larvae. Int. J. Syst. Bacteriol. 48 : 395-402.

Sabbahi, R., A. Merzouki, and C. Guertin. 2008. Efficacy of Beauveria bassiana against the strawberry pests, Lygus lineolaris, Anthonomus signatus and Otiorhynchus ovatus. J. Appl. Entomol. 132: 151-160.

Tumlinson, J.H., M.G. Klein, R.E. Doolittle, T.L. Ladd, and A.T. Proveaux. 1977. Identification of the female Japanese beetle sex pheromone: inhibition of male response by an enantiomer. Science $197:$ 789-792.

Vandenberg, J.D., M. Ramos, and J.A. Altre. 1998. Doseresponse and age- and temperature-related susceptibility of the diamondback moth (Lepidoptera: Plutellidae) to two isolates of Beauveria bassiana (Hyphomycetes: Moniliaceae). Environ. Entomol. 27 : 1017-1021.

Villani, M.G., S.R. Krueger, P.C. Schroeder, F. Consolie, N.H. Consolie, and L.M. Preston-Wilsey. 1994. Soil application effects of Metarhizium anisopliae on Japanese beetle (Coleoptera: Scarabaeidae) behavior and surviva in turfgrass microcosms. Environ. Entomol. 23 : 502-513.

Yamaguchi, T., H. Bando, and S.-i. Asano. 2013. Identification of Bacillus thuringiensis Cry8Da toxin-binding glucosidase from the adult Japanese beetle, Popillia japonica. J. Invertebr. Pathol. 113 : 123-128. 